Jurnal Pengurusan 55(2019) $97-109$

https://doi.org/10.17576/pengurusan-2019-55-08

\title{
Internal Corporate Social Responsibility Practices and Employees' Job Satisfaction in a Malaysian Banking Company
}

\author{
(Amalan Tanggungjawab Sosial Korporat Dalaman dan Kepuasan Kerja di Sebuah Syarikat \\ Perbankan Malaysia) \\ Tak Jie Chan \\ (Faculty of Communication and Creative Design, SEGi University) \\ Nurul Ain Mohd Hasan \\ (Faculty of Modern Languages and Communication, Universiti Putra Malaysia)
}

\section{ABSTRACT}

This study aims to examine the relationship between internal corporate social responsibility (CSR) practices and job satisfaction of employees in a Malaysian banking company. The study utilised Carroll's revised pyramid of global CSR and performance model with the selected CSR dimensions developed by Mohd Hasan (2013), consisting of the best global and local CSR practices. Multistage sampling, simple random sampling and convenient sampling was used. This study employed a quantitative (survey) method, wherein questionnaires were distributed to 342 bank staff (managerial and non-managerial), but only 174 valid responses were received. The data were analysed using Pearson-Product Moment Correlation test and Multiple Regression test through the Statistical Package for the Social Sciences (SPSS) version 22.0. The findings of multiple regression analysis revealed that human rights, labour rights and compliance with certified international standards pertaining to ethical and legal aspects of internal CSR were significant predictors of job satisfaction in the current context. Conclusion, limitations, implications of the findings, and suggestions for future study are also discussed.

Keywords: Banking company; business ethics; employees; internal corporate social responsibility; job satisfaction

\section{ABSTRAK}

Kajian ini bertujuan untuk mengkaji hubungan antara amalan tanggungjawab sosial korporat (TSK) dalaman dengan kepuasan kerja staf di sebuah syarikat perbankan di Malaysia. Kajian ini menggunakan model piramid TSK global dan prestasi yang dibina oleh Carroll dengan dimensi TSK terpilih yang dicadangkan oleh Mohd Hasan (2013) yang terdiri daripada amalan-amalan terbaik TSK global dan tempatan. Pensampelan berbilang, iaitu pensampelan rawak mudah dan pensampelan mudah telah diguna dalam kajian ini. Reka bentuk kajian ini ialah kuantitatif dengan menggunakan kaedah tinjauan. Borang soal selidik telah diedarkan kepada 342 staf bank (pengurusan dan bukan pengurusan), walau bagaimanapun, penyelidik hanya menerima sebanyak 174 respons. Data kemudiannya dianalisis dengan menggunakan ujian Korelasi Pearson dan ujian regresi berganda melalui Statistical Package for the Social Sciences (SPSS) versi 22.0. Dapatan kajian menunjukkan bahawa hak asasi manusia, hak pekerja dan pematuhan terhadap piawaian antarabangsa yang dikategori di bawah dimensi etika dan dimensi perundangan merupakan faktor peramal bagi meningkatkan kepuasan kerja staf. Kesimpulan, batasan kajian, implikasi dapatan dan cadangan untuk kajian masa depan juga dibincangkan.

Kata kunci: Syarikat perbankan; etika perniagaan; pekerja; amalan tanggungjawab sosial korporat dalaman; kepuasan kerja

\section{INTRODUCTION}

Corporate social responsibility (CSR) has been gaining greater attention from industries and scholars on a global level, causing developing countries to adapt existing global standards in order to compete in the international arena (Ozuem, Howell \& Lancaster 2014). According to Carroll and Shabana (2010), CSR acts as a driving force that promotes an ethical culture and climate in an organisation that yields multiple benefits. Numerous studies have proven that CSR is crucial for the success of a firm as CSR practices can help attract and retain employees (Obrad \& Gherheş 2018), improve the image, brand and reputation of an organisation (Ahmad Tarmidi,
Ariffin \& Adzharuddin 2016) and satisfy expectations of investors and customers, leading to an increase in financial performance (Kim, Hur \& Yeo 2015).

However, corporate scandals, fraudulent and unethical behaviours of multinational corporations such as Enron, Nike and WorldCom (Lee \& Sweeney 2014) raised attention in both developed and developing countries. The significance of CSR has become an important issue for banks as financial institutions. This is mainly because of the financial crisis, economic recession and unstable business environment which have increased people's level of distrust towards financial institutions. Hence, banks have begun to realise that the survival of their business is not merely focussed on economic aspects, 
such as profitability and growth, but also their desire to be portrayed as organisations that are socially responsible (McWilliams, Siegel \& Wright 2006).

According to Rahman, Gupta and Moudad-Ul-Huq (2012), the banking industry is valuable for the CSR study as it is the main pillar of the nation's economy and plays a pivotal role in improving social-economic welfare, such as monitoring borrowers, managing financial risks and organising the system of payments. Yeung (2011) further argued that banking institutions play a significant role in ensuring that banking resources are being utilised optimally to foster the competitive advantage and growth of the bank (Akpan 2016), by using innovation and human capital as resources (Guadamillas-Gómez \& Donate-Manzanares 2011). Thus, CSR initiatives allow legitimacy in banking practices, wherein initiatives of CSR provide long-term reputation management and create competitive advantages in the marketplace (Saeedina \& Shafeiha 2012).

Hence, the banking industry is more responsive to CSR's impact as it exposes it to wider multifaceted stakeholders in order to achieve their economic goals and maintain the work-life balance of its employees in particular (Akpan 2016). However, according to $\mathrm{Ng}$ (2008 in Ho, Ang \& Tee 2015), when it comes to the implementation of CSR practices, Malaysian public listed companies (PLCs) are still behind with regards to international standards as these companies have poor to mediocre CSR initiatives (Amran et al. 2013). This finding is in line with Lo and Yap's (2011) notion, wherein they state that more commitment from various bodies is required to make CSR sustainable in the future.

For instance, a study conducted by EY Asia-Pacific Fraud Survey (2017) showed that majority of current and potential employees (especially from generation Y) opt to leave and refuse to work for an organisation that uses unethical business practices. However, if organisations are socially responsible and fair in their CSR initiatives, employees will be encouraged to trust the corporation, perceive high value in terms of the relationship between the organisation and management, feel imperious and have a sense of belonging to the organisations (Aguilera et al. 2007). This supports the notion of Barkay (2012) that stakeholders are more willing to support corporations that practice CSR initiatives by addressing social issues. Hence, organisations start adopting CSR practices to lessen negative effects of their business and operations (Aguinis \& Glavas 2012), and thus, safeguarding their images and reputations. According to Ferreira and de Oliveira (2014), internal CSR provides a way to build a relationship between an organisation and its employees.

On the basis of the foregoing notions, internal CSR has become a significant aspect of attracting and retaining employees. This element is understandable since a better working environment and good internal relations help an organisation to enhance employee job satisfaction (Low \& Ong 2015) and increase their commitment (Edmans 2011). This conjecture is aligned with the concept of
Bakotić (2016) that satisfied and committed employees are vital assets which determine the success and survival of an organisation.

Prior research has addressed concerns regarding one particular issue in Malaysia which contradicts global CSR standards in terms of working hours and wages (Raman 2008). This has aligned with the notion of AlBattat and Som (2013) that the critical issue facing by the Malaysian service industry presently is employee job dissatisfaction, mainly caused by low salaries and uncomfortable working conditions. However, in 2014, the minimum wages were implemented to protect employees from falling into a lower socioeconomic status or get appointed to low-skilled positions to find employment in the various industries in Malaysia (Elangkovan 2012; Tin et al. 2014). That policy displayed the Malaysian government's concern for the development of human capital. In addition, there are issues related to child labour, occupational safety and health (Crinics 2010) that have drawn the attention of society with regards to the ethical practices of corporations towards their stakeholders. Hence, the focus of CSR initiatives towards addressing issues with labour and human rights remain critical among Malaysian workers (Lindgreen \& Swaen 2010; Chan \& Mohd Hasan 2015).

Although numerous studies have shown empirical findings related to CSR practices and different employee behaviours (Rupp 2011; Rupp et al. 2013), research on CSR practices that influence employees as internal stakeholders and their work attitude and behaviour need more exploration, particularly in the context of developing countries (Rahman, Haski-Leventhal \& Pournader 2016; Turker 2009a). Furthermore, the study of the effects of CSR initiatives on the attitude and behaviour of stakeholders, especially employees who work in the finance or banking sector is apparently lacking in developing countries (Albdour et al. 2010; Keraita, Oloko \& Elijah 2013; Chan 2014). Hence, this study aims to look into internal CSR initiatives among employees who work in the Malaysian banking industry and the implications of these initiatives towards employee job satisfaction.

Specifically, this study will be focusing on discovering the factors that may predict the determinants of internal CSR practices pertaining to ethical aspects (human rights, labour rights), and legal aspect (compliance with certified international standards) with respect to employee job satisfaction.

\section{LITERATURE REVIEW}

\section{INTERNAL CSR PRACTICES}

Internal CSR practices are related to the internal operations and practices of an organisation, concentrating on the employees' psychological and physiological state (Aguilera et al. 2007; Brammer, Millington \& Rayton 2007; Shen \& Zhu 2011). In particular, these practices provide employees with a good and safe working environment; enhance employees' skills and talents; 
ameliorate health and safety; procure employees' wellbeing; equality of opportunities; work-life balance; workfamily relationships; employees' satisfaction and loyalty and job quality (Ehnert, Harry \& Zink 2014; Low, Ong \& Tan 2017; Skudiene \& Auruskevicience 2012).

\section{THEORETICAL UNDERPINNING}

The theoretical underpinnings of this study are rooted in two models. First, this study is based on Carroll's (2004) revised pyramid of global CSR and performance model that consists of four (4) pillars, economic (be profitable), legal (obey the law), ethical (be ethical) and philanthropic (be a good corporate citizen) to suit the transnational CSR practice of accommodating global stakeholders. According to Matten and Moon (2008), in the Asian context, the best practices of CSR are embedded in codes of conducts as well as in government legislation. In addition, this study's foundations is based on the CSR dimensions and their relevancy in the Malaysian context as suggested by Mohd Hasan (2013), wherein she highlighted such internal CSR determinants are significant in Malaysia, given that the items were compiled and collated from existing global CSR best practices and local standards (Carroll 2004; Gray \& Gray 2011; Maignan \& Ferell 2001; Turker 2009b). The best CSR practice guidelines coupled with Carroll's revised pyramid of global CSR and performance model serve as a holistic CSR model that needs further exploration in Malaysia as a developing nation.

Since the current study focussed on internal stakeholders, which are the employees, the researchers of this study have only focussed on the two dimensions, ethical aspects (human rights and labour rights) and legal aspects (compliance with certified international standards). Doing so lines up well with the internal CSR practices of Bursa Malaysia (2008), wherein they focussed on workplace practices pertaining to diversity, gender issues, human capital development, quality of life, labour rights, human rights and health and safety (Muwazir, Hadi \& Yusof 2013).

\section{THE DIMENSION OF INTERNAL CSR PRACTICES}

Human Rights Human rights are indicated in statutes, including right to form labour unions and bargain collectively, right to work without being discriminated against and the right to work in a place which is healthful and safe (Gross 2012). Lindgreen and Swaen (2010) further argued that there are implications of CSR for human rights in developing countries, where they remain key issues in global settings. For instance, in developing countries like Malaysia, the area of human rights include respecting the right to practise one's religion, employees' awareness of human rights violations in a company's policies and adherence to local values, customs, and norms. Hence, this specification can further explain why organisations are required to be sensitive towards employees' religious beliefs and other local values and norms, such as allowing employees to perform their prayer routine, being sensitive to different cultures and values (Bursa Malaysia 2008; Mohd Hasan 2013, 2015). This is a particularly important aspect in the multifaceted and diverse Malaysian setting.

Such requirements have been further stressed by Ahmad and Ramayah (2012), where practising ethical human aspects of CSR in a multi-cultural country like Malaysia can be significant, since doing so represents some degree of harmony between organisations and society (as an entity). Thus, respecting human rights and responsibilities serves as a tool to help corporations manage and operate ethically.

Labour Rights Labour rights imply that organisational initiatives must communicate policies and practices relating to labour issues within or on behalf of the organisation. These rights include subcontracted work aligned with international labour standards (ILO) and local Malaysian employment practices. Labour CSR practices consist of organising activities that satisfy expectations of employees, including working hours that adhere to ILO standards, recruitment and promotion of employees, workplace health and safety, work environment, training and development of employees' skills, work-life balance, equitable wage or reward system and a transparent communication system (Amann \& Stachowicz-Stanusch 2013; Enhert et al. 2014; Mohd Hasan 2013; 2015).

Compliance with Certified International Standards Corporations are required to comply with laws and regulations as a condition of operating their businesses (Carroll 2016). This concept is supported by Mohamed, Jamaluddin and Muhammad Jamil (2014), who argue that compliance with certified legislation and regulatory requirements plays an important role for sustainability in PLCS. In Asian countries, complying with the accredited international standards like the International Organisation for Standardisation (ISO) was a common practise within CSR standards (Matten \& Moon 2008). Murphy and Yates (2009) further added that ISO 9000/9001 must serve to comprise organisational quality management practise. ISO $14001 / 14004$ is comprised of good corporate governance towards environmental stewardship and reducing energy consumption (ISO n. d.), whereas SA 8000 (Social Accountability International n. d.) comprises standards for employee relations. Occupational health and safety assessment (OHSAS) includes employee workplace security and accident prevention. In addition, Zinenko, Rovira and Montiel (2015) stressed that the implementation of ISO 26000 should complement CSR initiatives to effectively contribute to the sustainable development of firms. These principal standards are often practised by PLCs in developing countries (Mohd Hasan 2013, 2015). 
INTERNAL CSR PRACTICES AND ORGANISATIONAL OUTCOMES

Turker (2009a) investigated the relationship of CSR on various stakeholders, including employees and the results showed that CSR employees have a significant relationship with organisational commitment in the Turkey context. Besides, Liao and Teng (2010) investigated the effect of ethics training (labour practices) and employee satisfaction mediated by the CSR practices in Taiwan. Their findings indicated that ethics training positively influences CSR practices and in turn, CSR practices positively influence employees' satisfaction. Furthermore, the results showed that CSR practices served to partially mediate between ethics training and employees' satisfaction. Hence, employees' satisfaction can be enhanced through ethics training and CSR practices. The above findings also suggest increased organisational identification of employees, which often involve trust and incidentally, make employees more willing to practise ethical conduct in order to achieve organisational goals.

In another study, Tamm, Eamets and Mõtsmess (2010) examined the link between CSR and job satisfaction related to the well-being of employees in Baltic countries. Their findings showed that internal CSR practices were positively related to job satisfaction. This outcome is in line with Maignan, Ferrell and Ferrell (2005), where organisations can satisfy their employees through internal CSR initiatives by guaranteeing rewards and recognition, fostering personal development and work-life balance, ensuring occupational health and safety, enabling empowerment and work involvement, as well as providing better retirement compensation. Through their study, they also proved that organisations engaging in CSR activities will have favourable effects on employees' job assessment and performance, particularly in their role as internal stakeholders.

Santoso (2014) investigated the impact of internal CSR on employee engagement and affective commitment in the hospitality industry. The elements of internal CSR comprised of training and education, health and safety, human rights, work-life balance and workplace diversity. The findings indicated that health and safety were major predicting factors affecting employee engagement and affective commitment.

Therefore, the focus on health and safety as a labour practise is crucial in the working environment as it helps ensure not only work performance, but also increase in employee commitment. Furthermore, Kramer and Schmalenberg (2008) stated that health and safety measures can help reduce employee turnover, increase job satisfaction and reduce work-related stress and burnout among employees. This finding supported previous studies' conclusions about health and safety as being one of the components of internal CSR practices that have a significant influence on affective commitment of employees in the banking sector (Albdour et al. 2010; Keraita et al. 2013).
Cheruiyot and Maru (2014) tried to evaluate the effects of CSR human rights on employee job outcomes among three (3) leading horticultural exporters in Kenya. The findings indicated that organisations are largely satisfied that human rights protection is a moral obligation. In addition, regression results showed that CSR human rights has significant effect on human resource management outcomes, such as retention, satisfaction, commitment and pride. Based on their discussion, it implies that human rights CSR, particularly in complying with the law and regulations, is vital in enhancing employees' job outcomes and increase the performance of the organisations. This thought is further supported by Vinerean, Cetina and Dumitrescu (2013) that CSR policy is legitimate and appeals to attract talented employees as well as provide congenial work conditions to satisfy employees.

Thang and Fassin (2016) carried out a study to examine internal CSR and organisational commitment of employees in various Vietnamese service firms. The findings revealed that internal CSR (labour relations, health and safety, training and education) has a positive and significant effect on organisational commitment. However, the work-life balance and social dialogue had no significant relationship with organisational commitment. Based on the discussion of the findings, it can be concluded that the efforts of service firms regarding their internal CSR initiatives for work-life balance and social dialogue were insufficient. This study calls upon the management of service firms to strengthen and improve those initiatives for the amelioration of its employees.

Jayabalan et al. (2016) measured internal CSR attributes, namely health and safety, work-life balance, training and development, workplace diversity and compensation and benefits against organisational affective commitment. The results revealed that compensation and benefits are the most influential predictors impacting organisational affective commitment in Malaysian PLCs. Based on these findings, they suggested and explained that employees nowadays are more concerned about monetary rewards due to the changes in their lifestyles. Hence, besides providing attractive compensation, organisations need to create a sense of belonging among their workers by focussing on health and safety policies, supporting work-life balance among employees, offering training to improve human capital development, promoting diversity and avoiding discrimination in the workplace.

In Malaysian, Chan and Mohd Hasan (2016) examined the relation between determinants of CSR practices and intrinsic job motivation of employees in a public banking company. The study utilised the Bursa CSR framework with the integration of Mohd Hasan's (2013) best CSR practices dimensions. The findings showed that a CSR workplace is related to a firm's internal CSR practices, which have a positive and moderate relationship with intrinsic job motivation. Based on the discussion, workplace issues like human rights, labour rights, gender equality, health and safety of employees were shown to be related to employees' well-being needs, which had to 
be addressed fairly by organisations; such CSR elements contribute to employee motivation and commitment in the long run.

Furthermore, Chan (2016) examined the relationship between ethical dimensions of CSR with job satisfaction of employees in a public university. The study utilised CSR criteria based on Mohd Hasan (2013) that were developed and collated from extensive reviews of the CSR literature, particularly from Carroll's (2004) revised pyramid of global CSR and performance model, as well as existing global best practices, reflecting the Malaysian context in particular. Chan's (2016) findings revealed that human rights and labour rights under an ethical dimension have a positive and moderate relationship with the job satisfaction of employees. In addition, multiple regression analysis showed that labour rights was one of the predicting factors in job satisfaction within that public higher education institution. The discussion implies that in order to increase employee job satisfaction, educational institutions need to improve the labour CSR practices by emphasising equal opportunities for being promoted that are based on a meritocracy system, embedded in an ethical corporate governance initiative.

In addition, Low and Ong (2015) studies the internal CSR practices of small and medium-sized enterprises (SMEs) in the Klang Valley from the viewpoint of employees, regarding their attitudes and behaviours. The results showed that there is a positive relationship between internal CSR, which focuses on human resource and labour practices towards employees' organisational commitments and job satisfaction. The results also indicated that internal CSR can help reduce employee turnover. In other words, the value and benefits of internal CSR practices can help increase employee loyalty and make them more dedicated in their jobs.

Relatedly, Low et al. (2017) investigated internal CSR practices in the professional service industry. Their findings revealed that internal CSR practices have a vital role in the professional service industry. In addition, they found a direct relationship between internal CSR practices and the turnover intention, moderated by job satisfaction and organisational commitment. On the basis of the above discussion, the study showed that the practices of internal CSR varied within the industry. Furthermore, the internal CSR initiatives being practised by most of the organisations included providing career opportunities, well-being of employees, organisational justice and human rights policy.

When it comes to standards in CSR, Ward (2011) showed that standards such as ISO 9000 and ISO 14001 have become a yardstick for organisations to practise good business ethics and gain positive returns to reputation. This finding is in line with Castka and Balzarova (2007), wherein the quality of ISO 9000 helps organisations to achieve an excellent business performance by considering employees and workplace issues. They further added that the International Organisation for Standardisation (ISO 26000), which focuses on social responsibility actions, will help organisations operate in an ethical and transparent way in order to contribute to the health and welfare of the society including their employees (ISO 26000 n. d.). Hence, ISO 26000 serves as an informal law driving CSR actions.

Moreover, Valmohammadi (2014) valuated the seven core indicators of ISO 26000, namely, organisational governance, human rights, labour practices, environmental conditions, fair operating practices, consumer issues, and community involvement measured against organisational performance in Iranian organisations that focus on manufacturing and services. The findings revealed that the three (3) determinants of ISO 26000 (organisational governance, human rights, labour practices) had a significant relationship with organisational performance in Iran. On the basis of that discussion, ISO 26000 aims to provide guidelines for organisations to respect human rights, employment relationships, work conditions, social dialogue, health and safety, and human capital development. He further emphasised that this guideline is vital for job creation, economic and social aspects of employees as internal stakeholders.

Closon, Leys and Hellemans (2015) examined the perceptions of CSR with organisational commitment and job satisfaction as revealed in employee attitudes. The results indicated that job satisfaction is positively influenced by ethical-legal CSR practices. Furthermore, the results revealed that the ethical and legal CSR practices significantly influence affective organisational commitment. Based on the discussion above, ethical and legal CSR dimensions serve as guidelines to foster a worker's citizenship. This may potentially explain why employees are not only concerned about the ethical climate being generated by the organisation, but are also concerned about the actions of the organisation within the work environment.

Based on the foregoing ideas, this study hypothesises that:

$\mathrm{H}_{1} \quad$ Ethical CSR (human rights) positively influences employees' job satisfaction.

$\mathrm{H}_{2}$ Ethical CSR (labour rights) positively influences employees' job satisfaction.

$\mathrm{H}_{3}$ Legal CSR (compliance with certified international standards) positively influences employees' job satisfaction.

\section{METHODOLOGY \\ RESEARCH DESIGN}

This study employed a quantitative (survey) design, where a structured self-administered, anonymous questionnaire was distributed to the employees (both managerial and non-managerial) who were currently employed in a public banking institution, which served as the unit of analysis. Survey design was deemed to be a suitable method to apply in this study as it allows the researcher to effectively 
determine the opinions of respondents about a particular subject from a specific group of people (Babbie 2012).

\section{POPULATION AND SAMPLING}

This study was carried out in the public banking institution's headquarters with an estimated total population of 2,528 employees, whereby researchers received the number of employees from a top manager. A sample size of 342 was drawn from this population based on Yamane's (1973) formula, which is shown below:

$$
n=\frac{N}{1+N(e)^{2}}
$$

where, $\mathrm{n}$ is the sample size,

$N$ is the element of the population,

$e \quad$ is the sampling error, in this study, the sampling error was $5 \%$ or 0.05 in proportion

Example, $N=2,528$

$$
\begin{aligned}
& n=\frac{2,528}{1+2,528(0.05)^{2}} \\
& =\frac{2,528}{7.395} \\
& =341.85 \\
& \approx 342
\end{aligned}
$$

A multistage sampling procedure was then applied. Researchers used a probability sampling (simple random) to get a company from the list of banking companies that were listed under PLCs and applied nonprobability (convenience) sampling to solicit the data. The convenience sampling technique was used as the company was unable to provide a detailed list about the employees due to confidentiality issues. Hence, this limitation did not allow the researchers to utilise random sampling.

\section{PROCEDURES}

For the data collection, a structured anonymous questionnaire had been distributed to the employees (managerial and non-managerial) who were, at the time of data collection, working for the bank. Questionnaires were distributed during June - August 2016 (two months) with the help of the representative staff in the banking company. However, apart from the 342 samples that were determined, only 174 questionnaires held valid responses. According to Babbie (2012), a response rate that is above $50 \%$ is regarded as good and acceptable in social research surveys. The notion was in line with Sekaran and Bougie (2016) who argue that a sample size ranging from 30 to 500 is sufficient and acceptable for the social science studies. In addition, survey questionnaires were answered by participants based on their voluntary consent.

\section{THE INSTRUMENT}

The questionnaire consisted of three (3) sections. Section A was a demographic section and Section B included items pertaining to internal CSR practise, comprising human rights, labour rights and compliance with certified international standards. Section C contained items pertaining to job satisfaction. Demographic questions in Section A were designed to gather information about the respondents such as gender, category of staff, age, race, education level and tenure that the respondents were associated with. Section B dealt with specific dimensions of internal CSR that made up the three (3) best practices namely, human rights, labour rights and compliance with certified international standards drawn from many collated past studies (Carroll 2004; Gray \& Gray 2011; Maignan \& Ferell 2001; Turker 2009b) that are relevant to Malaysia. The survey items for Section B were measured based on a five-point Likert-type scale, where 1 represents "Strongly Disagree"; 2 represents "Disagree"; 3 indicates "Somewhat Agree"; 4 represents "Agree"; and 5 indicates as "Strongly Agree." Whereas, for Section C, the items were adopted from the Minnesota Satisfaction Questionnaire, MSQ (Weiss et al. 1967) measured on five-point Likert-type scale, where 1 indicates "Very Dissatisfied"; 2 represents "Dissatisfied; 3 indicates "Somewhat Satisfied"; 4 represents "Satisfied"; and 5 indicates "Very Satisfied."

\section{PILOT TESTING}

A pilot test was conducted to test the reliability, accuracy and consistency of the instrument. A total of 30 respondents (employees) from a private financial institution were chosen. According to Hair et al. (2015), the reliability analysis scale can be accepted if the Cronbach's alpha coefficient is between 0.6 and 1.0. In this study, it ranged from 0.693 to 0.920 (Table 1), making it acceptable and reliable.

Moreover, before multivariate analysis can be carried out, the data should be normally distributed, as normality is an important requirement for such analysis (Hair et al. 2018; Tabachnick \& Fidell 2013). Based on Table 2, the values for skewness and kurtosis for independent and dependent variables are in the range between -2 to +2 , with a $5 \%$ sampling error, which is considered acceptable to prove that a normal distribution exists (Tabachnick \& Fidell 2013). Hence, the data were normally distributed and the requirements for multivariate analysis were met.

In addition, multiple regression analysis was sensitive to multicollinearity problems. According to Tabachnick and Fidell (2013), multicollinearity happens when the independent variables are highly interrelated $(0.9$ and above). Hence, the variance inflation factor (VIF) and tolerance levels are used to analyse multicollinearity problems via the regression result derived from SPSS. As Hair et al. (2018) observed, the VIF should not exceed 10 
TABLE 1. Cronbach's alpha value of the variables

\begin{tabular}{lccc}
\hline \multicolumn{1}{c}{ Variable(s) } & $\begin{array}{c}\text { No. of } \\
\text { items }\end{array}$ & $\begin{array}{c}\text { Cronbach's } \\
\text { Alpha Value } \\
\text { (Pre-Test, } \mathrm{n}=30)\end{array}$ & $\begin{array}{c}\text { Cronbach's } \\
\text { Alpha Value } \\
\text { (Post-Test, } \mathrm{n}=174)\end{array}$ \\
\hline $\begin{array}{l}\text { Internal CSR Practices } \\
\text { Ethical dimension } \\
\text { Human Rights } \\
\text { Labour Rights }\end{array}$ & 5 & 0.809 & 0.801 \\
$\begin{array}{l}\text { Legal dimension } \\
\text { Compliance with Certified }\end{array}$ & 6 & 0.693 & 0.855 \\
$\quad \begin{array}{l}\text { International Standards } \\
\text { Job Satisfaction }\end{array}$ & 5 & & 0.752 \\
\hline
\end{tabular}

${ }^{*}$ Cronbach's alpha values in this study are based on Guilford Rule of Thumb

TABLE 2. Skewness and kurtosis of the variables

\begin{tabular}{lcccccc}
\hline \multicolumn{1}{c}{ Variable(s) } & Min & Max & Skewness & Kurtosis & Tolerance & VIF \\
\hline $\begin{array}{l}\text { Internal CSR Practices } \\
\text { Ethical dimension }\end{array} \quad$ & & & & & & \\
$\quad$ Human rights & 11.00 & 25.00 & 0.295 & -0.265 & 0.714 & 1.401 \\
$\quad \begin{array}{l}\text { Labour rights } \\
\text { Legal dimension }\end{array}$ & 11.00 & 25.00 & 0.237 & 0.263 & 0.702 & 1.424 \\
$\quad \begin{array}{l}\text { Compliance with certified } \\
\quad \text { international standards }\end{array}$ & 10.00 & 25.00 & 0.341 & 0.038 & 0.657 & 1.523 \\
Job Satisfaction & 40.00 & 100.00 & 0.272 & 0.287 & & \\
\hline
\end{tabular}

and the tolerance values are supposed to be more than 0.10 . On the one hand, Table 2 shows that the range of tolerance was between $0.657-0.714$, which is more than 0.10 . On the other hand, the VIF range was between 1.401 -1.523 , which is reasonable because it is less than 10 (Tabachnick \& Fidell 2013). Thus, it may conclude that no multicollinearity issues existed among the independent variables.

\section{RESULTS \& DISCUSSION}

Table 3 shows the correlations among the variables. Based on Table 3, it was shown that the correlation matrix among the dimensions of internal CSR, which focussed on ethical aspect: human rights $(r=0.407, p<0.05)$, labour rights $(r=0.428, p<0.05)$ and legal aspect, compliance with certified international standards $(r=0.443, p<$ 0.05 ) have a positive and moderate relationship with job satisfaction as a dependent variable. Hence, all the results indicate significant relationships. Thus, hypotheses $\mathrm{H}_{1}$, $\mathrm{H}_{2}$ and $\mathrm{H}_{3}$ are accepted. Congruently, when employees perceived internal CSR dimensions, ethical and legal dimensions (human rights, labour rights and compliance with certified international standards) more positively, their job satisfaction increases. This outcome supports the findings of the previous studies pertaining to employees' perceptions about internal CSR practices being positively related to employees' job satisfaction (Low \& Ong 2015; Low et al. 2017; Rahman et al. 2016; Tamm et al. 2010).
TABLE 3. Correlation test for the relationship between dimensions of internal CSR practices and job satisfaction of employees $(n=174)$

\begin{tabular}{lcc}
\hline & Job & Satisfaction \\
\cline { 2 - 3 } $\begin{array}{l}\text { Dimensions of Internal } \\
\text { CSR Practices }\end{array}$ & $r$ & $p$ \\
\hline Ethical dimension & & \\
$\quad$ Human rights & & \\
$\quad$ Labour rights & $0.407^{* *}$ & 0.000 \\
Legal dimension & $0.428^{* *}$ & 0.000 \\
$\quad \begin{array}{l}\text { Compliance with certified } \\
\quad \text { international standards }\end{array}$ & $0.443^{* *}$ & 0.000 \\
\hline
\end{tabular}

${ }^{* *}$ Correlation is significant at the 0.01 level (1-tailed)

Furthermore, the findings indicated that human rights is a component of internal CSR practices that influenced employees' job satisfaction, coinciding with the findings of previous study (Cheruiyot \& Maru 2014). The possible explanation of the result suggests that practising ethical human aspects of CSR in Malaysia as a multi-cultural country is important and relevant as it represents the harmony of the organisation and society as an entity (Ahmad \& Ramayah 2012). Thus, an organisation has an obligation to instil human rights to protect the legitimacy of the organisation's CSR goals and initiatives.

In addition, labour rights practices that are related to the workplace were also found to have significant results with employee satisfaction, which support prior findings noted in the literature (Chan 2016; Liao \& Teng 2010), 
along with the compliance with certified international standards, yielding similar results (Chan \& Mohd Hasan 2018; Closon et al. 2015; Valmohammadi 2014). A possible interpretation of this finding suggests that in the banking institution understudied do not have many issues related to labour rights as stipulated by the ILO standards, wherein the banking institution accommodate to the regulations and the culture of the nation where it operates. This has further explained that employees' commitment and satisfaction with their jobs were strongly related to the law and regulations, wherein such policies were aligned with the practise found in corporate governance parameters.

Besides, the findings are also congruent with the study conducted by Mory, Wirtz and Göttel (2016) that employees' perceived implementation of internal CSR as organisations' synergy efforts have a connection with the employees. This aspect finds further support in Brammer et al. (2007) that suggest internal CSR needs to be considered when implementing organisational CSR pertaining to employees. This further explains that internal CSR acts as a tool in an employee relations management strategy because ethical CSR helps incite and impel employee trust in the organisation.

Based on the explanation, it can be concluded that the organisation should try their best to keep their employees satisfy and engaged them in CSR practices to create a shared valued for the society. For instance, the banking company should develop policies in order to satisfy their employees' needs to ensure they feel the company as home. Besides, the company should also communicate more frequently and transparently with the employees in order to understand the condition of employees' attitudes, commitment and citizenship behaviour.

Table 4 summarises the results of multiple regression analysis regarding job satisfaction explained by the dimensions of internal CSR practices. The $\mathrm{R}$ value of 0.529 shows a moderate correlation between job satisfaction and the overall predicting variables (internal CSR practices). The analysis of variance with $\mathrm{F}=22.013$ was significant at the 0.05 level of significance. While the three (3) predictors collectively contributed to $26.7 \%$ of the variation. The analysis clearly indicated that human rights, labour rights and compliance with certified international standards under the ethical and legal dimensions of internal CSR practices were the factors that contributed to job satisfaction of bank employees. However, there are some other variables $(73.3 \%)$ that were not explained in this study that contribute incrementally to job satisfaction.

TABLE 4. Multiple regression analysis of job satisfaction with predictor variables

\begin{tabular}{lccc}
\hline Predictor Variables & Unstandardised & Coefficient & \multirow{2}{*}{ Standardised Coefficients } \\
\cline { 2 - 3 } Internal CSR Dimension & $\mathrm{B}$ & Std. Error & $\mathrm{B}$ \\
\hline (Constant) & 24.347 & 5.255 & 0.000 \\
Human rights & 0.718 & 0.283 & 0.000 \\
Labour rights & 0.677 & 0.233 & 0.226 \\
Compliance with certified international & 0.837 & 0.288 & 0.234 \\
standards & & & 0.004 \\
\hline
\end{tabular}

$\mathrm{F}=22.013 \mathrm{df}_{1}=3, \mathrm{df}_{2}=170 \mathrm{P}=0.000 \mathrm{R}=0.529 \mathrm{R}^{2}=0.280$ Adjust $\mathrm{R}^{2}=0.267$

Nejati and Ghasemi (2013) showed results that are congruence with the current findings, in that their result showed that CSR pertaining to employees was positively related to organisational commitment in Iran, a developing country. In addition, Keraita et al. (2013) found that internal CSR (workplace diversity, work-life balance, training and safety) were predictors positively related to employee commitment. This outcomes proved that labour CSR practices positively influence organisational effects on employee satisfaction (Chan 2016; Chan \& Mohd Hasan 2016; Liao \& Teng 2010; Santoso 2014; Thang \& Fassin 2016).

Based on the results, the study contributes to the theoretical links between CSR and the job satisfaction, which are payment and compensation, nature of work, career opportunities/advancement, supervision, workload, co-worker relations, and working conditions (Asrar-ulHaq, Kuchinke \& Iqbal 2017; Tamm et al. 2010). This has shown that organisations' that practise worklife balance initiatives by adopting flexible working arrangements, such as job sharing, flexible working timetable, paid time off policies, and sponsored family activities or events will eventually help to increase the employees' satisfaction that adheres to the labour practices.

In addition, Mohd Hasan (2013) showed that compliance with certified international standards was the feature least reported by Malaysian organisations, while organisations adhered more to health and safety issues. This result might be explained by the fact that private corporations focus more on health and safety issues (OHSAS 18001) in their social reports because Malaysian organisations are likely to hire foreign workers. This finding was in line with the previous literature suggesting that the health and safety issues have become significant elements of concern by organisations in relation to employees (Albdour et al. 2010; Kramer \& Schmalenberg 2008; Santoso 2014). 
Based on the findings, the organisation that emphasises on employees' health and safety during works is one of the significant labour issues in the industry. Health and safety are concerned with protecting human and facility recourses in the workplace, whereby it is one of the company's obligation to lessen any accidents that caused death and injuries happen to their employees. Hence, organisations need to invest facilities to ensure that the working environment is favourable for the employees. For instance, the organisation needs to ensure the devices and equipment are functioning properly, having comfortable working condition, no harassment, and other improper conduct. This showed that health and safety working conditions will make the employees feel more secure and thus will increase their organisational satisfaction and commitment.

These results were also in line with the findings of Jayabalan et al. (2016) that compensation and benefits as part of labour CSR practices are the most influential predictors affecting the organisational affective commitment in Malaysian PLCs. Likewise, organisations that provide training and development as an ethical labour practise for their employees to enhance their career advancement, also tend to increase employee morale and job satisfaction (Liao \& Teng 2010), where an employee will be more willing to stay with the organisation when the organisation is supportive and concern with the welfare of the employees by providing adequate training which help them to develop skills that improve work competency and performance.

Hence, this practise will help reduce job turnover and increase productivity in the workplace (Low et al. 2017). Wherein, it is timely for a workforce to receive proper training and skills to attain more knowledge for the advancement of human capital development, driving organisations successfully towards sustaining their business and operation (Longo \& Mura 2011). Compliance with legitimate and legal standards, as well as the ethical aspect of internal CSR, will eventually help enhance employees' job satisfaction in the workplace (Closon et al. 2015; Valmohammadi 2014).

Based on the discussion, it can be concluded that employees are likely to engage with organisations that highly involved in CSR initiatives. Employees' perceptions towards organisation's social ethics and services serve the betterment of the society have an influence on employees' attitudes and job performance by enhancing the belongingness of the employees toward the organisations. In addition, employee perceptions of CSR, as the key internal stakeholders are important as they potentially contribute to organisational commitment and will help increase employee morale and loyalty in return. Hence, managers of banking companies should highlight the ethical-legal CSR dimension in their recruitment campaigns to attract prospective employees.

The positive results of this study support the notion that employees in the particular banking company perceived labour and human rights policies positively.
For instance, the banking company gave their employees training and education for the advancement of personal growth and achievement. Besides that, the company also respected the rights to practise one's own religion and adhered to various local values, customs and norms. Thus, these practises influenced employees to have stronger job commitments within the organisation. This finding supports an idea that the ethical engagement of employees is a prominent key factor in CSR agenda-building in corporations.

In summary, based on the foregoing discussion, organisations should embed internal CSR initiatives as part of their strategy to achieve sustainability. This recommendation is made because social responsibility initiatives help gain competitive advantages for the development of stakeholders and organisations over the long run, which will have a significant impact on attracting prospective employees as well as retaining the current ones.

\section{CONCLUSION}

This study describes the relationship between internal CSR practices and job satisfaction of employees in a Malaysian banking organisation. The empirical findings show that human rights, labour rights and compliance with certified international standards are the predicting variables under internal CSR practices that can help to enhance employee satisfaction. In terms of knowledge-based implications, this study provides support for the best global and local contextualised CSR practices dimensions developed by Mohd Hasan (2013), integrating with the ethical and legal elements from Carroll's (2004) revised pyramid of global CSR and performance model by adding investigation from the Malaysian context. Eventually, the body of knowledge in the CSR arena is enhanced.

\section{MANAGERIAL IMPLICATIONS}

In terms of practical implications, the findings provide insights for the management of organisations to offer their employees the practices of internal CSR. In order to retain a talented and committed workforce in this turbulent business environment, it behoves top management to create a sense of belonging and pride among the employees. Thus, the top management should adopt and highlight ISO 2600, which focusses on internal CSR practices and initiatives such as corporate governance, human rights and labour practices in the workplace, to enhance employees' satisfaction, morale and commitment. This will potentially lead to an increase in productivity and effectiveness of the organisations.

The management of the banking company studied should plan several CSR related programmes to improve the understanding of CSR knowledge among the employees. For instance, they can conduct courses or seminars to 
introduce the employees to the company's CSR policies and programmes, given that CSR is a top-down strategy that not all employees are aware of. In addition, increasing employee job satisfaction in the bank requires an informed staff with respect to the labour rights practices found under ethical CSR elements. The employees should have access to the information related to the human resource practices, such as a training and education that may help promote career advancement. Besides, equal opportunities for promotion based on the merit should be applied rather than following bureaucratic management systems that base advancement on seniority.

\section{LIMITATIONS \& FUTURE DIRECTIONS}

There are several limitations in the study. First, the sample size of the study cannot be generalised to the population of the bank studied, given that it was based on voluntary and convenient sampling. Thus, future studies should increase the number of respondents so that the sample better represents the population. Moreover, it would be interesting to include more organisations under the same sector or other industries to add some new perspectives to the research and increase its validity.

Another limitation exists regarding the issue of social desirability bias, wherein respondents may answer according to what they think is socially desirable, as employees are scared that the data might be shown to top management and consequently produce some negative effects on their jobs. However, the researchers attempted to minimise this limitation by creating an anonymous instrument and assuring respondents of the data's confidentiality.

This study tested a model composed of three (3) key internal CSR practices pertaining to ethical and legal dimensions. Future studies may include other factors such as leadership management style, corporate reputation, employees' motivations, employee engagement and test their moderating or mediating effects under the expected CSR model and its relationship with organisational outcomes.

\section{ACKNOWLEDGEMENT}

This research was supported by the Putra Research Grant (Project no.: GP-IPS/2015-9461900) of Universiti Putra Malaysia. The authors would also like to thank the two anonymous reviewers for their constructive and valuable comments to strengthen this article, as well as Research and Innovation Management Centre of SEGi University for providing the professional editing services to edit this article.

\section{REFERENCES}

Aguilera, R.V., Rupp, D.E., Williams, C.A. \& Ganapathi, J. 2007. Putting the $S$ back in corporate social responsibility: A multilevel theory of social change in organisations. Academy of Management Review 32(3): 836-863.

Aguinis, H. \& Glavas, A. 2012. What we know and don't know about corporate social responsibility: A review and research agenda. Journal of Management 38(4): 932-968.

Ahmad, N.H. \& Ramayah, T. 2012. Does the notion "doing well by doing good" prevail among entrepreneurial ventures in a developing nation? Journal of Business Ethics 106(4): 479-490.

Ahmad Tarmidi, N.F., Ariffin, S.N.A. \& Adzharuddin, N.A. 2016. Corporate social responsibility and branding co-existence practices in Bank Simpanan Nasional and AgroBank in Malaysia. Asian Journal Applied Communication 6(1): 51-60.

Akpan, E.O. 2016. Enhancing the CSR of the banks for growth and performance improvement: A theoretical perspective. Global Journal of Commerce \& Management Perspectives 5(3): 51-56.

AlBattat, A.R.S. \& Som, A.P.M. 2013. Employee dissatisfaction and turnover crisis in the Malaysian hospitality industry. International Journal of Business and Management 8(5): 62-71.

Albdour, A.A., Ali, A., Nasruddin, E. \& Soh, K.L. 2010. The relationship between internal corporate social responsibility and organisational commitment within the banking sector in Jordan. International Scholarly and Scientific Research \& Innovation 4(7): 852-871.

Amran, A., Zain, M.M., Sulaiman, M., Sarker, T. \& Ooi, S.K. 2013. Empowering society for better corporate social responsibility (CSR): The case of Malaysia. Kajian Malaysia 31(1): 57-78.

Asrar-ul-Haq, M., Kuchinke, K.P. \& Iqbal, A. 2017. The relationship between corporate social responsibility, job satisfaction, and organisational commitment: Case of Pakistani higher education. Journal of Cleaner Production 142: 2352-2363.

Babbie, E.R. 2012. The Practice of Social Research. $13^{\text {th }}$ edition. Belmont: Wadsworth.

Bakotić, D. 2016. Relationship between job satisfaction and organisational performance. Economic Research - EkonomskaIstraživanja 29(1): 118-130.

Barkay, T. 2012. Employee volunteering: Soul, body and CSR. Social Responsibility Journal 8(1): 48-62.

Brammer, S., Millington, A. \& Rayton, B. 2007. The contribution of corporate social responsibility to organisational commitment. International Journal of Human Resource Management 18(10): 1701-1719.

Bursa Malaysia. 2008. Corporate social responsibility (CSR) framework for Malaysian public listed companies. Available at http://www.klse.com.my/website/bm/about_us/the organisation/csr/download/csr_writeup.pdf

Carroll, A.B. 2004. Managing ethically with global stakeholders: A present and future challenge. Academy of Management Review 18(2): 114-120.

Carroll, A.B. \& Shabana, K.M. 2010. The business case for corporate social responsibility: A review of concepts, research and practice. International Journal of Management Review 12(1): 85-105. 
Carroll, A.B. 2016. Carroll's pyramid of CSR: Taking another look. International Journal of Corporate Social Responsibility 1(3): 1-8.

Castka, P. \& Balzarova, M.A. 2007. A pathway to "CSR Excellence": The roles of ISO 9000 and ISO 26000. Proceedings of the $12^{\text {th }}$ International Conference on ISO 9000 and TQM, edited by Ho, S.K.M., April 2007, Taiwan.

Chan, C.W. 2014. The impact of corporate social responsibility on employees' attitude and behaviour: Financial services industry. Unpublished Master of Business Administration thesis, Universiti Tunku Abdul Rahman, Malaysia. Available at http://eprints.utar.edu.my/ 2439/1/CHAN CHE_WEE_1101586.pdf

Chan, T.J. 2016. The relationship between ethical and discretionary dimensions of corporate social responsibility practices and job satisfaction of employees in a Malaysian public university. Unpublished Master's thesis, Universiti Putra Malaysia, Selangor, Malaysia.

Chan T.J. \& Mohd Hasan, N.A. 2015. The influence of corporate social responsibility (CSR) practices on job satisfaction and corporate reputation based on employees' perspective. Asian Journal Applied Communication 5(2): 1-15.

Chan, T.J. \& Mohd Hasan, N.A. 2016. Determinants of corporate social responsibility (CSR) and intrinsic job motivation: A case of Malaysian banking company. Malaysian Journal of Social Sciences and Humanities 1(2): 25-35.

Chan T.J. \& Mohd Hasan, N.A. 2018. Predictors of employees' job satisfaction through corporate social responsibility (CSR) practices in Malaysian banking company. Advanced Science Letters 24(5): 3072-3078.

Cheruiyot, T.K. \& Maru, L.C. 2014. Corporate human rights social responsibility and employee job outcomes in Kenya. International Journal of Law and Management 56(2): 152-168.

Closon, C., Leys, C. \& Hellemans, C. 2015. Perceptions of corporate social responsibility, organisational commitment and job satisfaction. Management Research: The Journal of the Iberoamerican Academy of Management 13(1): 31-54.

Crinis, V. 2010. Sweat or no sweat: Foreign workers on the garment industry in Malaysia. Journal of Contemporary Asia 40(1): 589-611.

Edmans, A. 2011. Does the stock market fully value intangible? Employee satisfaction and equity prices. Journal of Financial Economics 101(3): 621-640.

Ehnert, I., Harry, W. \& Zink, K.J. 2014. Sustainability and Human Resource Management: Developing Sustainable Business Organisations. New York: Springer Heilderberg.

Elangkovan, K. 2012. Minimum wage laws in Malaysia: An answer to the increasing rate of unemployment. International Journal of Academic Research in Economics and Management Sciences 1(5): 135-146.

EY Asia-Pacific Fraud Survey 2017. Trend confirmed: employees won't work for unethical companies. Available at https:// fraudsurveys.ey.com/ey-asia-pacific-fraud-survey-2017/ trend-confirmed-employees-won-t-work-for-unethicalcompanies/

Ferreira, P. \& de Oliveira, E.R. 2014. Does corporate social responsibility impact on employee engagement? Journal of Workplace Learning 26(3/4): 232-248.

Gray, R. \& Gray, S. 2011. Accountability and human rights: A tentative exploration and a commentary. Critical Perspectives on Accounting 22(8): 781-789.
Gross, J.A. 2012. The human rights movement at U.S. workplaces: Challenges and changes. Industrial and Labor Relations Review 65(1): 3-16.

Guadamillas-Gómez, F. \& Donate-Manzanares, M.J. 2011. Ethics and corporate social responsibility integrated into knowledge management and innovation technology. Journal of Management Development 30(6): 569-581.

Hair, J.F., Celsi, M., Money, A., Samouel, P. \& Page, M. 2015. Essential of Business Research Methods. $3^{\text {rd }}$ edition. New York: Routledge.

Hair, J.F., Black, W.C., Babin, B.J. \& Anderson, R.E. 2018. Multivariate Data Analysis. $8^{\text {th }}$ edition. Cengage Learning EMEA.

Ho, J.A., Ang, Y.H. \& Tee, K.K. 2015. Institutional corporate social responsibility (CSR) practices: The influence of leadership styles and their perceived ethics and social responsibility role. Pertanika Journal of Social Sciences \& Humanities 23(S): 17-32.

ISO. n.d. Protecting our planet: ISO standards for the environment. Available at https://www.iso.org/protectingour-planet.html

ISO 26000 . n.d. In ISO 26000 - social responsibility. Available at http://www.iso.org/iso/home/standards/iso26000.htm

Jayabalan, J., Appannam, J., Low, M.P. \& Koay, S.M. 2016. Perception of employee on the relationship between internal corporate social responsibility (CSR) and organisational affective commitment. Journal of Progressive Research in Social Sciences 3(2): 168-175.

Kramer, M. \& Schmalenberg, C. 2008. Confirmation of healthy work environment. Critical Care Nurse 28(2): 56-63.

Keraita, J.M., Oloko, M.A. \& Elijah, C.M. 2013. The influence of internal corporate social responsibility on employee commitment in the banking sector: A survey of commercial banks in Kisii town, Kenya. International Journal of Arts and Commerce 2(1): 59-76.

Kim, H., Hur, W.M. \& Yeo, J. 2015. Corporate brand trust as a mediator in the relationship between consumer perception of CSR, corporate hypocrisy and corporate reputation. Sustainability 7(4): 3683-3694.

Lee, W.E. \& Sweeney, J. 2014. Use of discretionary environmental accounting narratives to influence stakeholders: The case of jurors' award assessments. Journal of Business Ethics 129(3): $1-16$

Liao, W-C. \& Teng M-Y. 2010. The relationship between ethics training and employee satisfaction: A mediator of corporate responsibility practices. The Journal of Human Resource and Adult Learning 6(1): 9-18.

Lindgreen, A. \& Swaen, V. 2010. Corporate social responsibility. International Journal of Management Reviews 10(1): 53-73.

Lo, B.C. \& Yap, K. 2011. Are Malaysian ready for corporate social responsibility? Labuan e-Journal of Muamalat and Society 5: 11-15

Longo, M. \& Mura, M. 2011. The effect of intellectual capital on employees' satisfaction and retention. Information and Management 48(7): 278-287.

Low, M.P. \& Ong, S.F. 2015. The manifestation of internal corporate social responsibility on employees' behaviour in small medium sized enterprises. Journal of Social Sciences Studies 2(2): 259-277.

Low, M.P., Ong, S.F. \& Tan, P.M. 2017. Would internal corporate social responsibility make a difference in professional service industry employees' turnover intention? A two- 
stage approach using PLS-SEM. Global Business and Management Research: An International Journal 9(1): 24-41.

Maignan, I. \& Ferrell, O.C. 2001. Antecedents and benefits of corporate citizenship: An investigation of French business. Journal of Business Research 51(1): 37-51.

Maignan, I., Ferrell, O.C. \& Ferrell, L. 2005. A stakeholder model for implementing social responsibility in marketing. European Journal of Marketing 39(9/10): 956-977.

Matten, D. \& Moon, J. 2008. "Implicit" and "explicit CSR: A conceptual framework for a comparative understanding of corporate social responsibility. Academy of Management Review 33(2): 404-424.

McWilliams, A., Siegel, A.D. \& Wright P.M. 2006. Corporate social responsibility: Strategic implications. Journal of Management Studies 43(1): 1-18.

Mohd Hasan, N.A. 2013. Towards achieving global standards: The role of public relations in processes and outcomes of corporate social responsibility initiatives in Malaysia. $\mathrm{PhD}$. dissertation, Massey University, Wellington, New Zealand. Avaiable at http://mro.massey. ac.nz/handle/10179/4706

Mohd Hasan, N.A. 2015. Communicating corporate social responsibility: How message in text influence the standards. Journal of Language and Communication 2(2): 105-118.

Mory, L., Wirtz, B.W. \& Göttel, V. 2016. Corporate social responsibility strategies and their impact on employees' commitment. Journal of Strategy and Management 9(2): 172-201.

Mohamed, R., Jamaluddin, N.A. \& Muhammad Jamil, C.Z. 2014. Corporate sustainability drivers and strategy: Evidence from Malaysian public-listed companies. Proceedings of the Australian Academy of Business and Social Sciences Conference 2014. Available at https://www.aabss.org. au/system/files/published/AABSS2014_136.pdf

Murphy, C.N. \& Yates, J. 2009. The International Organisation for Standarisation (ISO), Global Governance through Voluntary Vonsensus. New York: Routledge.

Muwazir, M.R., Hadi, N.A. \& Yusof, M. 2013. Measuring corporate social responsibility commitments in the Malaysian financial services industry. American-Eurasian Journal of Sustainable Agriculture 7(4): 430-434.

Nejati, M. \& Ghasemi, S. 2013. Corporate social responsibility and organisational commitment: Empirical findings from a developing country. Journal of Global Responsibility 4(2): 263-275.

Obrad, C. \& Gherheş, V. 2018. A human resources perspective on responsible corporate behavior. Case study: the multinational companies in Western Romania. Sustainability 10(726): 1-15.

Ozuem, W., Howell, K. \& Lancester, G. 2014. Corporate social responsibility towards a context-specific perspective in developing countries. Social Responsibility Journal 10(3): 399-415.

Rahman, M.M., Gutpa, D.A. \& Moudud-Ul-Hug, S. 2012. Job satisfaction of female employees in financial institutions of Bangladesh: A study on selected private commercial banks. Global Journal of Management and Business Research 12(14): 49-55.

Rahman, S., Haski-Leventhal, D. \& Pournader, M. 2016. The effect of employee CSR attitude on job satisfaction and organisational commitment: Evidence from the Bangladeshi banking industry. Social Responsibility Journal 12(2): 228-246.
Raman, R. 2008. Impact of multinational corporation in Malaysia. Malaysia Trades Union Congress Subang Jaya, Malaysia. Available at http://www.global-labouruniversity.org/fileadmin/GLU_conference_Unicamp_2008/ Submitted_papers/Impact_of_Multinational_Corporation_ in_Malaysia_by_Rajeswari_Raman.pdf

Rupp, D.E. 2011. An employees-centered model of organisational justice and social responsibility. Organisational Psychology Review 1(1): 72-94.

Rupp, D.E., Shao, R., Thornton, M.A. \& Skarlicki, D.P. 2013. Applicants and employees' reactions to corporate social responsibility: The moderating effects of first party justice perceptions and moral identity. Personnel Psychology 66(4): 895-933.

Santoso, I.L. 2014. The impact of internal CSR towards employee engagement and affective commitment in XYZ hotel Surabaya. iBuss Management 2(2): 79-88.

Saeednia, H. \& Shafeiha, S. 2012. Investigation the link between competitive advantage and corporate social responsibility from consumer's view. International Journal of Economics \& Business Modeling 3(2): 177-182.

Sekaran, U. \& Bougie, R. 2016. Research Methods for Business: A Skill Building Approach. $7^{\text {th }}$ edition. New Jersey: John Willey and Sons, Inc.

Shen, J. \& Zhu, C.J. 2011. Effects of socially responsible human resource management on employee organizational commitment. The International Journal of Human Resource Management 22(15): 3020-3035.

Skudience, V. \& Auruskevicience, V. 2012. The contribution of corporate social responsibility to internal employee motivation. Baltic Journal of Management 7(1): 49-67.

Social Accountability International. n.d. SA8000 standard. Available at http:// www.sa-intl.org/index. cfm? fuseaction=Page. ViewPage\&PageID=937

Tabachnick, B.G. \& Fidell, L.S. 2013. Using Multivariate Statistic. $6^{\text {th }}$ edition. Boston: Pearson Education Inc.

Tamm, K., Eamets, R. \& Mõstmees, P. 2010. Are employees better off in social responsible firms? Discussion papers series, IZA DP No. 5407. Available at http://ftp.iza.org/ dp5407.pdf

Thang, N.N. \& Fassin, Y. 2016. The impact of internal corporate social responsibility on organisational commitment: Evidence from Vietnamese service firms. International Business Management 10(6): 784-792.

Tin, P.L., Yusof, M.F., NikMahmood, N.H. \& Tan, H.S. 2014. The implementation of minimum wages in Malaysia. Sains Humanika 2(2): 43-36.

Turker, D. 2009a. How corporate social responsibility influences organisational commitment. Journal of Business Ethics 85(2): 189-204.

Turker, D. 2009b. Measuring corporate social responsibility: A scale development study. Journal of Business Ethics 85(4): 411-427.

Valmohammadi, C. 2014. Impact of corporate social responsibility practices on organisational performance: An ISO 26000 perspective. Social Responsibility Journal 10(3): 455479.

Vinerean, S., Cetina, I. \& Dumitrescu, L. 2013. Modelling employee satisfaction in relation to CSR practices and attraction and retention of top talent. Expert Journal of Business and Management 1(1): 4-14.

Ward, H. 2011. The ISO 26000 international guidance standard on social responsibility: Implications for public policy 
and transnational democracy. Theoretical Inquires in Law 12(2): 665-718.

Weiss, D.J., Dawis, R.V., England, G.H. \& Lofquist, L.H. 1967. Manual for the Minnesota Satisfaction Questionnaire. Minnesota Studies in Vocational Rehabilitation, XXII.

Yamane, T. 1973. Statistics: An Introductory Analysis. $2^{\text {nd }}$ edition. New York: Harper and Row.

Yeung, S. 2011. The role of banks in corporate social responsibility. Journal of Applied Economics and Business Research 1(2): 103-115.

Zinenko, A., Rovira, M.R. \& Montiel, I. 2015. The fir of the social responsibility standard ISO 26000 within other CSR instruments: Redundant or complementary? Sustainability Accounting, Management and Policy Journal 6(4): 498526.

Tak Jie Chan (corresponding author)

School of Communication Studies

Faculty of Communication and Creative Design

SEGi University

No. 9. Jalan Teknologi, Taman Sains Selangor

Kota Damansara, PJU 5

47810 Petaling Jaya, Selangor, MALAYSIA.

E-Mail: chantakjie@segi.edu.my

Nurul Ain Mohd Hasan

Department of Communication

Faculty of Modern Languages and Communication

Universiti Putra Malaysia

43400 UPM Serdang, Selangor, MALAYSIA.

E-Mail: namh@upm.edu.my 